\title{
Identification of androgen receptor protein and $5 \alpha$-reductase mRNA in human ocular tissues
}

\author{
Eduardo M Rocha, L Alexandra Wickham, Lilia A da Silveira, Kathleen L Krenzer, \\ Fu-Shin Yu, Ikuko Toda, Benjamin D Sullivan, David A Sullivan
}

\begin{abstract}
Backgroundlaims-Androgens have been reported to influence the structural organisation, functional activity, and/or pathological features of many ocular tissues. In addition, these hormones have been proposed as a topical therapy for such conditions as dry eye syndromes, corneal wound healing, and high intraocular pressure. To advance our understanding of androgen action in the eye, the purpose of the present study was twofold: firstly, to determine whether tissues of the anterior and posterior segments contain androgen receptor protein, which might make them susceptible to hormone effects following topical application; and, secondly, to examine whether these tissues contain the mRNA for types 1 and/or 2 $5 \alpha$-reductase, an enzyme that converts testosterone to the very potent metabolite, dihydrotestosterone.
\end{abstract}

Methods-Human ocular tissues and cells were obtained and processed for histochemical and molecular biological procedures. Androgen receptor protein was identified by utilising specific immunoperoxidase techniques. The analysis of type 1 and type $25 \alpha$-reductase mRNAs was performed by the use of RT-PCR, agarose gel electrophoresis, and DNA sequence analysis. All immunohistochemical evaluations and PCR amplifications included positive and negative controls.

Results-These findings show that androgen receptor protein exists in the human lacrimal gland, meibomian gland, cornea, bulbar and forniceal conjunctivae, lens epithelial cells, and retinal pigment epithelial cells. In addition, our results demonstrate that the mRNAs for types 1 and $25 \alpha$-reductase occur in the human lacrimal gland, meibomian gland, bulbar conjunctiva, cornea, and RPE cells.

Conclusion-These combined results indicate that multiple ocular tissues may be target sites for androgen action.

(Br f Ophthalmol 2000;84:76-84)
During the past several decades, it has become quite apparent that androgens exert a significant influence on the structural organisation, functional activity, and/or pathological features of many ocular tissues, including the lacrimal gland, meibomian gland, conjunctiva, cornea, lens, uvea, and/or retina. ${ }^{1-16}$ The nature of this hormone action appears to involve the regulation of such ocular factors as glandular morphology, gene expression, protein synthesis and secretion, lipid production, tear film stability, immune function, epithelial cell mitosis, aqueous outflow pathway characteristics, intraocular pressure, and vascular permeability. ${ }^{1-5} 101^{13-16}$ In addition, androgens have been proposed as a topical therapy for such conditions as aqueous deficient and evaporative dry eye syndromes, corneal wound healing, and glaucoma. ${ }^{267131617}$ However, despite these findings, very little information exists concerning the precise target cells for androgen action, the specific ocular processes controlled by these hormones, or the mechanisms underlying androgen-eye interactions in humans.

The mechanism(s) by which androgens act on the human eye most likely involves the local, intracrine synthesis of these hormones from adrenal sex steroid precursors (that is, dehydroepiandrosterone (DHEA) and DHEA sulphate (DHEA-S)) and a consequent androgen association with saturable, high affinity, and steroid specific receptors in ocular tissues. ${ }^{18} 19$ The rationale for this hypothesis is twofold. Firstly, a large proportion of androgens in men, and the majority of these hormones in women, are produced in peripheral tissues from adrenal precursors. ${ }^{18}$ In fact, humans and primates are unique in possessing adrenal glands that secrete large amounts of DHEA and DHEA-S, which are then converted into potent androgens and oestrogens by steroidogenic enzymes in peripheral sites and thereby permit target tissues to adjust the formation and metabolism of sex steroids to local requirements. ${ }^{18} 20$ Secondly, androgen receptors, which are members of the steroid/thyroid hormone/retinoic acid family of ligand activated transcription factors, appear to mediate almost all of the "classic" actions of androgens. ${ }^{19}$ The location of androgen receptor protein is predominantly intranuclear because of the existence of a 
nuclear targeting signal, similar to that of the SV 40 large $T$ antigen, which occurs in the receptor hinge region immediately following the DNA binding domain. ${ }^{21}$ After androgen binding to the receptor, the monomeric, activated hormone receptor complex associates with an androgen response element in the regulatory region of specific target genes, typically dimerises with another androgen bound complex and, in combination with appropriate silencers, co-activators, tissue specific, and basal promoter elements, controls gene transcription. ${ }^{19} 22$ This androgen activity induces an alteration in mRNA production and eventually protein synthesis in a variety of tissues. ${ }^{1922}$

In support of this hypothesis, investigators have found that several steroidogenic enzymes exist in the rat and/or rabbit cornea, iris, ciliary body, lens, and retina, and that these enzymes are involved in the formation or catabolism of androgens. ${ }^{23-26}$ In addition, we have discovered that androgen receptor mRNA is present in the lacrimal gland, meibomian gland, palpebral and bulbar conjunctivae, cornea, iris/ciliary body, lens, retina/uvea, and/or retina/choroid of mice, rats, hamsters, guinea pigs, and/or rabbits (Wickham LA, Gao J, Toda I, et al, manuscript submitted). ${ }^{27}{ }^{28}$ Moreover, we and others have observed that: (a) androgen receptor protein occurs within epithelial cell nuclei of lacrimal glands of mice, rats, and hamsters ${ }^{29}{ }^{30}$; (b) rat lacrimal glands contain a single class of saturable, high affinity and steroid specific androgen binding sites, which possess a dissociation constant and stereochemical selectivity analogous to those found in numerous cells and tissues throughout the body ${ }^{27}{ }^{31}$; (c) androgen receptor complexes in rat lacrimal tissue adhere to $\mathrm{DNA}^{31}$; (d) androgens control the accumulation of various mRNA species, and enhance or attenuate the synthesis of many proteins, in the lacrimal gland ${ }^{1}$; (e) androgen effects in rat lacrimal tissue or isolated acinar epithelial cells may be suppressed by antagonists of, or mutations within, androgen receptors, as well as by inhibitors of transcription and translation ${ }^{32-35}$; and (f) androgen binding sites exist in the bovine corneal epithelium. ${ }^{36} 37$

These findings, though, do not address the potential mechanism(s) by which androgens act on the human eye. However, we have recently discovered that androgen receptor mRNA is present in the lacrimal gland, meibomian gland, bulbar conjunctiva, cornea, and retinal pigment epithelial (RPE) cells from women and/or men (Wickham LA, Gao J, Toda I, et al, manuscript submitted). If these transcripts are translated, then numerous ocular sites may be target organs for androgens, and may be susceptible to hormone action following local synthesis and/or topical application. Therefore, the purpose of the present study was to examine whether androgen receptor mRNA is translated in sufficient amounts to permit the identification of androgen receptor protein in the anterior and posterior segments of the human eye. As a corollary to this objective, we also sought to determine whether human ocular tissues contain the mRNA for types 1 and/or $25 \alpha$-reductase. This steroidogenic enzyme governs a critical pathway in the local synthesis of androgens and is responsible for converting testosterone to a very potent metabolite, dihydrotestosterone (DHT)..$^{18} 20$

\section{Materials and methods}

HUMAN TISSUES AND CELL LINES

Human lacrimal glands, lower lids, bulbar and forniceal conjunctivae, corneas, and prostatic tissue were obtained during surgical procedures (ocular tissues were generously provided by Drs Devinder P Cheema, John Choi, Elizabeth Daher, Kenneth Kenyon, Masafumi Ono, Peter A. Rapoza, John W Shore and Daniel J Townsend, Boston, MA, USA) and meibomian glands, when indicated, were isolated from human lid tissues. Samples were frozen immediately after collection and stored in liquid nitrogen until experimental use. Human retinal pigment epithelial (RPE) cells were generously donated by Dr Kathleen Dorey (Boston, MA, USA) and maintained in RPMI 1640 medium (Gibco/BRL, Grand Island, NY, USA), 1\% penicillin-streptomycin (Gibco/BRL) and 10\% fetal bovine serum (FBS; Hyclone, Logan, UT, USA) in a $37^{\circ} \mathrm{C}$ humidified incubator containing $5 \%$ carbon dioxide. Human lens epithelial cells were generously provided by Dr Toshi Shinahara (Boston, MA, USA) and cultured in DMEM-low glucose (Gibco/BRL), $0.1 \%$ gentamicin sulphate (Gibco/BRL), and 10\% FBS in the $37^{\circ} \mathrm{C}$ humidified chamber containing $5 \%$ carbon dioxide. Two human cell lines were obtained from American Type Culture Collection (ATCC; Rockville, MD, USA), including Hs68 fibroblasts (foreskin, ATCC No CRL 1635 ) and $\mathrm{LNCaP}$ epithelial cells (prostate carcinoma, clone FGC, ATCC No CRL 1740). These cell lines were cultured according to the recommendations of ATCC. In addition, an RNA sample from a male lacrimal gland was generously donated by $\mathrm{Dr}$ John Ubels (Grand Rapids, MI, USA), human prostate total RNA was acquired from Clontech Laboratories (Palo Alto, CA, USA), and corneal tissues were purchased from the New England Eye Bank (Boston, MA, USA). These research studies were approved by the human studies committee of the Schepens Eye Research Institute (Boston, MA, USA) and were conducted in accordance with guidelines established by the Declaration of Helsinki.

\section{ANIMAL TISSUES}

Young adult male Sprague-Dawley rats (6 weeks old) were obtained from Zivic-Miller Laboratories (Allison Park, PA, USA) and housed in constant temperature rooms with light/dark intervals of 12 hours' duration. Following animal sacrifice, prostates were removed, embedded in OCT compound (Miles Laboratories Inc, Naperville, IL, USA) and stored in liquid nitrogen until experimental utilisation. All studies with these animals adhered to the Association for Research in Vision and Ophthalmology resolution on the use of animals in research. 
IMMUNOHISTOCHEMICAL PROCEDURES

To examine the distribution of androgen receptor protein in ocular tissues and cells, samples were evaluated according to published immunohistochemical procedures. ${ }^{29}$ In brief, frozen human tissues were placed in OCT compound and cut at $-20^{\circ} \mathrm{C}$ into $6 \mu \mathrm{m}$ sections. Sections were transferred to poly-L-lysine coated glass slides (Sigma Chemical Co, St Louis, MO, USA) and fixed in acetone (JT Baker, Phillipsburg, NJ, USA). The RPE, lens epithelial, and $\mathrm{LNCaP}$ cells were grown to $>90 \%$ confluence and attached cells were washed with HBSS (Gibco/BRL), removed from the culture plates by trypsin/EDTA (Gibco BRL) treatment, cytocentrifuged (Shandon, Inc, Pittsburgh, PA, USA) onto poly-L-lysine coated glass slides $\left(10^{5}\right.$ cells/slide), and fixed in acetone for 5 minutes at $4^{\circ} \mathrm{C}$. After sequential exposure of slides to $4 \%$ paraformaldehyde (Sigma) and a 2\% "normal" goat serum solution (Vector Laboratories, Burlingame, CA, USA), sections were overlaid with an aliquot of purified rabbit polyclonal antibody to the human and rat androgen receptor $(2 \mu \mathrm{g}$ antibody/ml; gift from Dr Gail S Prins, Chicago, IL, USA), or appropriate control solutions. These control preparations included: (1) $0.1 \%$ gelatin (Fisher Scientific, Medford, MA, USA) in PBS (0.05 M sodium phosphate, 0.15 M sodium chloride, $\mathrm{pH} 7.3$ ); (2) irrelevant rabbit IgG antibodies (ICN Biomedicals, Inc, Costa Mesa, CA, USA); and (3) rabbit anti-androgen receptor antibody, after antibody preincubation for 60 minutes at $4^{\circ} \mathrm{C}$ with either peptide "AR 1-21" or "AR 462-478" (donations from Dr Prins). The "AR 1-21" competitor contained the first 21 amino acids of the androgen receptor and had been used to generate the original antibody. ${ }^{38}$ The "AR 462-478" peptide was derived from a distant part of the androgen receptor (that is, amino acid residues 462 to 478) and was not reactive with the rabbit anti-receptor antibody. ${ }^{38}$ Following incubation with first antibody for 2 hours or overnight in a humidified chamber at $4^{\circ} \mathrm{C}$, sections were incubated with different avidin $\mathrm{D}$ and biotin solutions, then with a biotinylated goat antirabbit IgG antibody (Vector). The secondary antibody had previously been incubated overnight at $4^{\circ} \mathrm{C}$ with mouse liver acetone powder at a concentration of $60 \mathrm{mg} / \mathrm{ml}$ in $0.1 \%$ gelatin/ PBS. After second antibody exposure, sections were placed in Vectastain Elite ABC reagent (Vector), developed with an acetate buffer containing 3-amino-9-ethylcarbazole (Sigma), $\mathrm{N}, \mathrm{N}$-dimethylformamide and hydrogen peroxide, postfixed in $2 \%$ paraformaldehyde, dipped in a lithium carbonate (Aldrich Chemical Co, Milwaukee, WI, USA) solution, and preserved in Crystal Mount (Biomeda, Foster City, CA, USA). Throughout this immunohistochemical protocol, the administration of various reagents to sections was interspersed with either air drying or the rinsing of slides with PBS or double distilled water. To confirm antibody reactivity in individual experiments, sections of rat prostate glands were included as positive (that is, with first antibody) and negative (that is, with rabbit IgG or gelatin/PBS) control tissues. ${ }^{29} 38$
Photographs depicting the immunohistochemical location of androgen receptors in ocular tissue sections and cells were obtained by using a Nikon Eclipse E800 microscope at various magnifications and a Spot v1 $1 \mathrm{CE}$ Diagnostic Instruments, Inc, Image System (Micro Video Instruments, Avon, MA, USA). Images were imported into Adobe Photoshop 4.01 on a Power Macintosh $8600 / 200$ with 96 MB RAM and printed with a Kodak XLS 8600 printer.

MOLECULAR BIOLOGICAL PROCEDURES

To identify types 1 and $25 \alpha$-reductase mRNA in human tissues and cells, reverse transcription polymerase chain reactions (RT-PCR) were used. Total RNA was purified from samples by utilising TRI-Reagent (Molecular Research Center, Inc, Cincinnati, OH, USA). The resulting RNA isolates were quantitated by spectrophotometry at $260 \mathrm{~nm}$ and evaluated on $6.6 \%$ formaldehyde $1.2 \%$ agarose (Gibco/BRL) gels to verify RNA integrity. cDNAs were then transcribed from RNA samples (between 2.5 and $6.8 \mu \mathrm{g} / \mathrm{sample}$ ) by using MMLV reverse transcriptase, oligo dT priming and the Advantage RT-for-PCR kit from Clontech Laboratories Inc (Palo Alto, CA, USA), according to modifications of the manufacturer's protocol.

PCR amplification of the cDNAs (2.7-6 $\mu \mathrm{l} /$ sample) was conducted with a Perkin Elmer Cetus GeneAmp PCR System 9600 (Perkin Elmer, Norwalk, CT, USA) by employing Taq DNA polymerase (Gibco/BRL; 1.5 units), 0.3 $\mathrm{mM}$ each of dATP, dCTP, dGTP, and dTTP (Perkin-Elmer), PCR buffer (Invitrogen PCR buffer $\mathrm{M}$ or N: $60 \mathrm{mM}$ TRIS-HCl, $1.5 \mathrm{mM}$ (type 1) or $2.0 \mathrm{mM}$ (type 2) $\mathrm{MgCl}_{2}, 15 \mathrm{mM}$ $\left(\mathrm{NH}_{4}\right)_{2} \mathrm{SO}_{4}, \mathrm{pH} \mathrm{10}$ ), and $0.36-0.40 \mu \mathrm{M}$ each of $5^{\prime}$ and $3^{\prime}$ primers corresponding to types 1 ( $5^{\prime}$ $\rightarrow$ 3' nucleotide sequences: sense: GGC CAT GTT CCT CGT CCA CTA C; antisense: AGT CCA TAG AGA AGC GCC ATT G) and $2\left(5^{\prime} \rightarrow 3^{\prime}\right.$ nucleotide sequences: sense: GAA CCT GGG TGG CTT ATG AG; antisense: GCC CCT TCC TTA GAG AGT CC) $5 \alpha$-reductase cDNAs. Oligonucleotide primers and internal probes, which were synthesised by National Biosciences, Inc (Plymouth, MN, USA), were designed by reference to GenBank sequences (accession numbers M32313 and M74047). ${ }^{39} 40$ The PCR programme involved the following cycle profile: 35 cycles of denaturation for 1 minute at $94^{\circ} \mathrm{C}$, annealing for 1 minute at $54^{\circ} \mathrm{C}$, extension for 1 minute at $72^{\circ} \mathrm{C}$, and maximisation of strand completion for 6 minutes at $72^{\circ} \mathrm{C}$. Following amplification, the cDNA fragments were analysed on $1.5 \%$ agarose gels, that contained a 100 bp DNA molecular weight ladder (Gibco/ BRL) and were post-stained with ethidium bromide, to confirm the anticipated 578 and $628 \mathrm{bp}$ sizes for the types 1 and $25 \alpha$-reductase products, respectively. In all PCR procedures, positive and negative control $\mathrm{cDNAs}$ were run in parallel, but separate, tubes. Positive controls for types 1 and $25 \alpha$-reductase mRNAs included cDNAs prepared from human prostatic tissues, Hs68 fibroblasts, and LNCaP 
Table 1 Identification of androgen receptor protein in epithelial cell nuclei of human ocular tissues and cells

\begin{tabular}{|c|c|c|c|c|c|c|}
\hline \multirow[b]{2}{*}{ Tissue } & \multirow[b]{2}{*}{ Sex } & \multirow[b]{2}{*}{ Age } & \multirow[b]{2}{*}{ Pathology } & \multicolumn{3}{|c|}{ Androgen receptor staining } \\
\hline & & & & $\begin{array}{l}\text { 1st Antibody } \\
\text { without } \\
\text { competitor }\end{array}$ & $\begin{array}{l}\text { 1st Antibody with } \\
\text { "AR 462-478”" } \\
\text { peptide }\end{array}$ & $\begin{array}{l}\text { 1st Antibody with } \\
\text { "AR 1-21" } \\
\text { peptide }\end{array}$ \\
\hline Lacrimal gland & female & 70 & & + & + & - \\
\hline Lacrimal gland & male & elderly & hypertrophy & + & + & - \\
\hline Meibomian gland & female & 48 & ectropion & + & + & - \\
\hline Meibomian gland & female & 70 & entropion & + & + & - \\
\hline Meibomian gland & male & 85 & & + & + & - \\
\hline Meibomian gland & male & 88 & chalazion & + & + & - \\
\hline Bulbar conjunctiva & female & 77 & & + & + & - \\
\hline Bulbar conjunctiva & female & 79 & cataract & + & + & - \\
\hline Bulbar conjunctiva & male & 27 & corneal scar and cataract & + & + & - \\
\hline Bulbar conjunctiva & male & 38 & keratoconus & + & + & - \\
\hline Bulbar conjunctiva & male & 70 & aphakia & + & + & - \\
\hline Bulbar conjunctiva & male & 85 & cataract & + & + & - \\
\hline Forniceal conjunctiva & male & 55 & & + & + & - \\
\hline Cornea & female & 65 & herpes simplex keratitis & & + & - \\
\hline Cornea & male & 27 & corneal scar and cataract & + & + & - \\
\hline Cornea & male & 38 & keratoconus & & + & - \\
\hline Lens epithelial cells & male & 13 & cataract & + & + & - \\
\hline RPE cells & male & 71 & cardiac arrest & + & + & - \\
\hline
\end{tabular}

$\mathrm{RPE}=$ retinal pigment epithelial.

Tissues and cells were obtained and processed as described in the Materials and methods. To verify the specificity of staining, aliquots of the rabbit anti-human androgen receptor antibody were preincubated with excess amounts of either peptide "AR 1-21", which was used to elicit the original antibody, or peptide "AR 462-478", which was derived from a non-reactive part of the androgen receptor. These aliquots, or the first antibody alone (that is, without a competiting peptide), were then used in the immunoperoxidase procedure. Under these conditions, the AR 1-21, but not the AR 462-478, peptide should prevent specific androgen receptor staining.

epithelial cells. ${ }^{41-43}$ Negative control tubes contained either DEPC treated water or water plus the reaction mixture, but without the cDNA template.

Further verification of cDNA product identity was performed by Southern blot hybridisation and DNA sequence analysis. For Southern blots, the amplified cDNA fragments were transferred to GeneScreen nylon membranes (Dupont/NEN, Boston, MA, USA) by positive

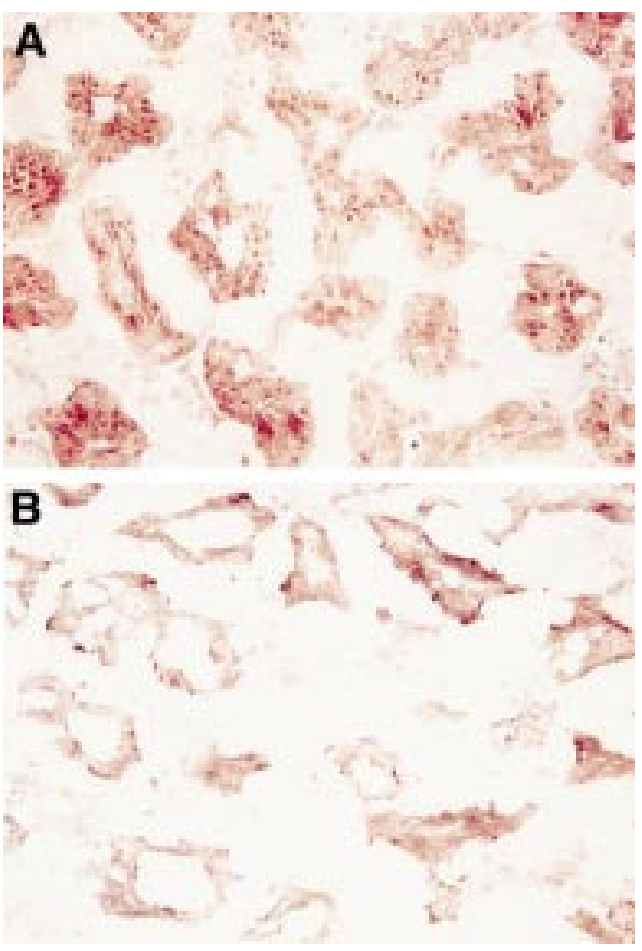

Figure 1 Identification of androgen receptor protein in epithelial cell nuclei of the lacrimal gland. The tissue was obtained from an elderly man during ocular surgery and processed for immunoperoxidase procedures. To confirm the specificity of first antibody staining $(A)$, an aliquot of the rabbit anti-human androgen receptor was preincubated with an excess amount of peptide "AR1-21" (B). pressure (Posi-Blot Pressure Blotter, Stratagene, La Jolla, CA, USA), fixed by ultraviolet cross linking and incubated with specific ${ }^{32} \mathrm{P}$ labelled oligomeric probes in a buffer containing 5X SSC, 5X Denhardt's solution, 0.5\% SDS, and $100 \mu \mathrm{g}$ sonicated salmon sperm $\mathrm{DNA} / \mathrm{ml}$ in $0.1 \%$ DEPC treated water. The internal oligomeric probes for type $1\left(5^{\prime} \rightarrow 3^{\prime}\right.$ : CCA AGG CGC GGC TTT TGC TT) and 2 $\left(5^{\prime} \rightarrow\right.$ 3': CTG CTT GCC TCC ACC AGA TG) 5 $\alpha$-reductase were radiolabelled with $\gamma-{ }^{32} \mathrm{P}$-dATP (Amersham, Arlington Heights, IL, USA) by the end labelling method with T4 Polynucleotide Kinase (New England BioLabs, Beverly, MA, USA). Radiolabelled probes were separated from free ${ }^{32} \mathrm{P}$ nucleotides by passage through appropriately sized Sephadex columns (Pharmacia, Piscataway, NJ, USA). After an overnight hybridisation in an oscillating water bath, the Southern blots were washed and processed for autoradiography by using Kodak X-OMAT AR film (Kodak, Rochester, NY, USA) with an intensifying screen at $-80^{\circ} \mathrm{C}$. DNA sequence analysis was performed by purifying amplified cDNA fragments with a Qiaquick Spin PCR Purification Kit (Qiagen Inc, Chatsworth, CA, USA) and sequencing these samples with a Pharmacia Cycle Sequencing Kit (Pharmacia, Piscataway, NJ, USA). These reactions included $2 \mu \mathrm{l}$ PCR products, 3 pmol of oligomeric primers and $1 \mu 1 \alpha{ }^{32} \mathrm{P}$-dCTP $(50 \mu \mathrm{Ci})$ and were run for 25 cycles in a Biometra Personal Cycler (Biometra, Tampa, FL, USA) under the following conditions: $95^{\circ} \mathrm{C}$ for 30 seconds, $55^{\circ} \mathrm{C}$ for 36 seconds, and $72^{\circ} \mathrm{C}$ for 84 seconds. Resulting samples were electrophoresed on $6 \%$ DNA sequencing gels and processed for autoradiography by using Fuji X-ray film (Fuji Medical Systems, Stamford, CN, USA) at $-80^{\circ} \mathrm{C}$. Sequence specificity for types 1 and 2 $5 \alpha$-reductase mRNA was evaluated by utilising GenBank analysis. 


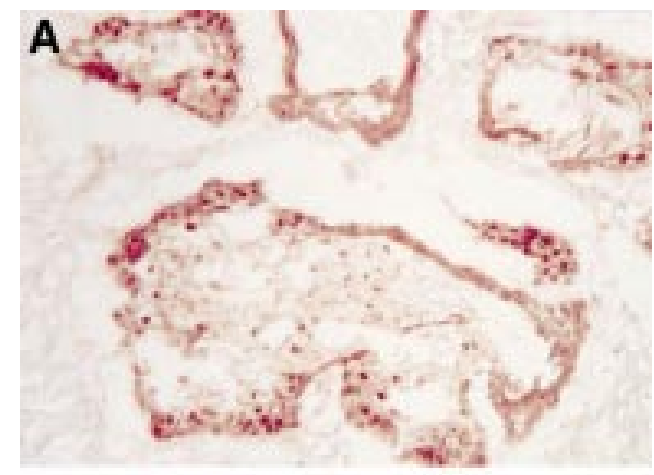

B

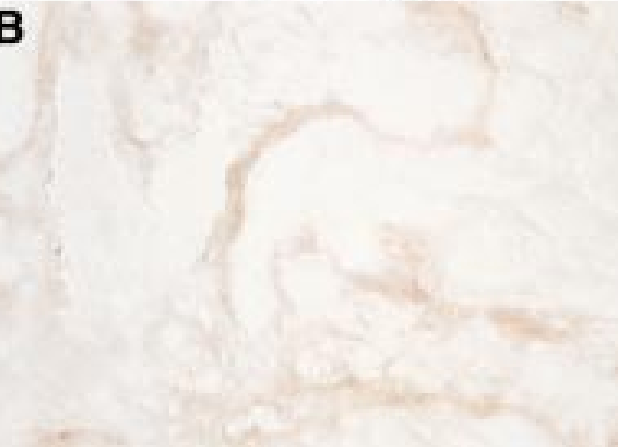

Figure 2 Presence of androgen receptor protein in the nuclei of acinar epithelial cells of the meibomian gland. The tissue was obtained from a 70 year old woman during plastic surgery for lid reconstruction. Immunoperoxidase staining of the tissue sample was performed with a first antibody that had been preincubated with either peptide "AR462-478" (A) or peptide "AR1-21" (B).

\section{Results}

IDENTIFICATION OF ANDROGEN RECEPTOR

PROTEIN IN TISSUES AND CELLS OF THE ANTERIOR AND POSTERIOR SEGMENTS

To examine whether tissues and cells of the anterior and posterior segments of the human eye contain androgen receptor protein, the following study was performed. Lacrimal glands $(n=2)$, lower lid tissues $(n=4)$, bulbar conjunctivae $(n=6)$, forniceal conjunctiva $(n=1)$, corneas $(n=3)$, lens epithelial cells, and RPE cells were obtained from females and/or males, and processed for immunohistochemistry to permit evaluation of the cellular distribution and the intracellular location of androgen receptor protein (Table 1). For comparative and/or control purposes, $\mathrm{LNCaP}$ cells and rat prostates were also examined for androgen receptor staining.

Our results demonstrate that androgen receptor protein exists in epithelial cells of the human lacrimal gland, meibomian gland, bulbar and forniceal conjunctivae, cornea, lens, and retina (Table 1). As shown in Figures 1 and 2 , androgen receptor protein was located almost exclusively within epithelial cell nuclei of lacrimal glands and acinar epithelial cell nuclei of meibomian glands. Similarly, androgen receptor protein was identified in epithelial cell nuclei throughout the bulbar conjunctiva (Fig 3). This conjunctival staining, which was apparent at all levels of the epithelium, occurred predominantly in the upper cellular layer. Androgen receptor protein was also present in the nuclei of epithelial cells of the forniceal conjunctiva, apical epithelial cells of the cornea (Fig 4), lens epithelial cells (Fig 5),
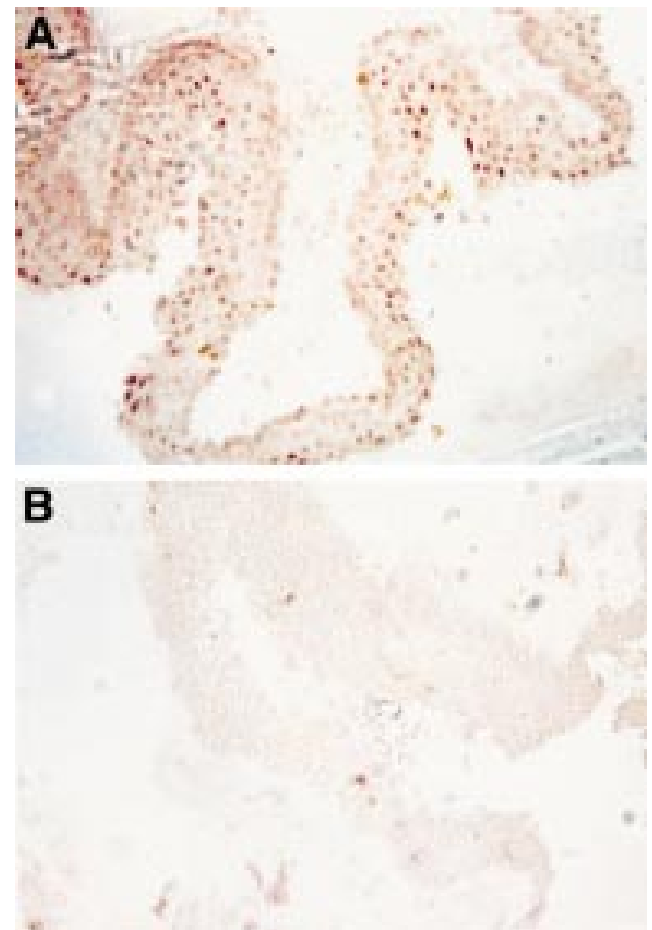

Figure 3 Location of androgen receptor protein in epithelial cell nuclei of the conjunctiva. The tissue was obtained from a 79 year old woman during an extracapsular crystalline extraction and then processed for immunoperoxidase procedures. To verify the specificity of first antibody staining $(A)$, an aliquot of the rabbit anti-human androgen receptor was preincubated with an excess amount of peptide "AR1-21" (B).

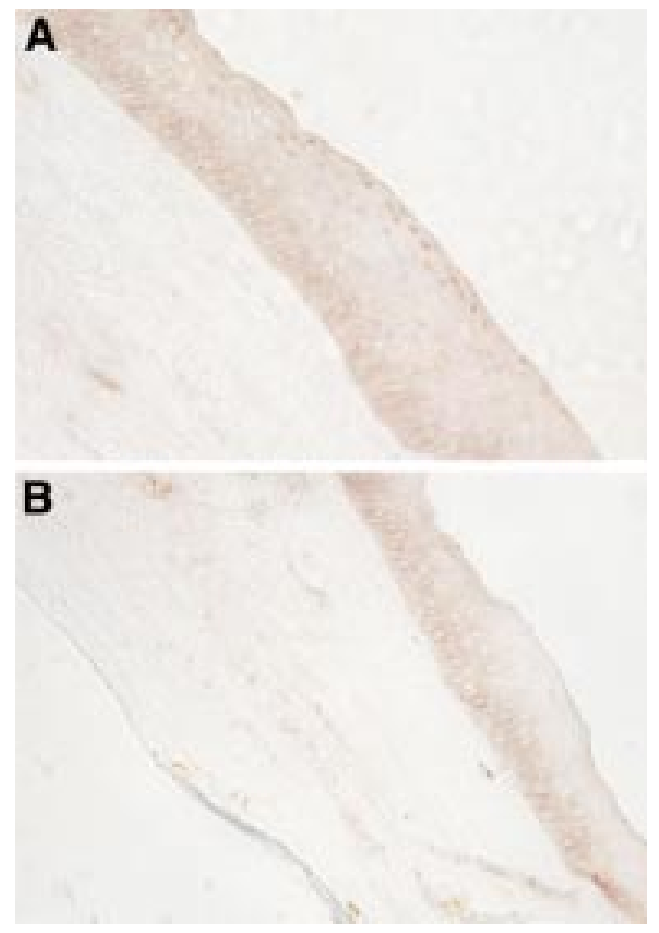

Figure 4 Identification of androgen receptor protein in the nuclei of apical epithelial cells of the cornea. The tissue was obtained from a 65 year old woman during keratoplastic surgery. Immunoperoxidase analysis of the tissue sample was conducted with a first antibody that had been preincubated with either peptide "AR462-478" (A) or peptide "AR1-21" (B). 


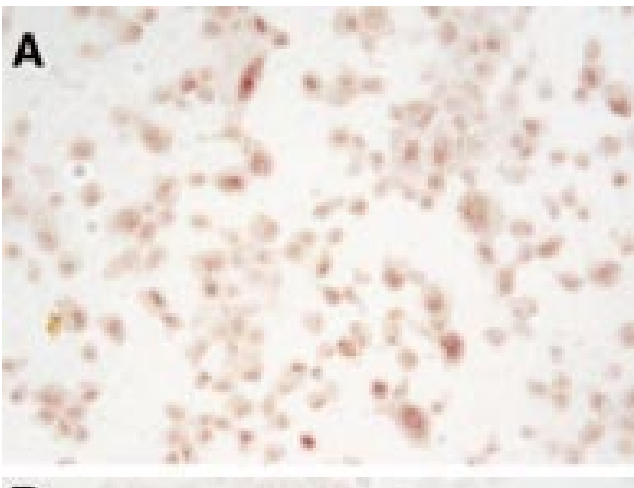

B

Figure 5 Presence of androgen receptor protein in the nuclei of lens epithelial cells. The lens cells were obtained from a 13 year old male undergoing cataract surgery and were then cultured, cytocentrifuged onto poly-L-lysine coated glass slides $\left(10^{5}\right.$ cells/slide), fixed in acetone for 5 minutes at $4^{\circ} \mathrm{C}$, and processed for immunoperoxidase procedures. Staining was performed with a first antibody that had been preincubated with either peptide "AR462-478" $(A)$ or peptide "AR1-21" (B). Competition with this latter peptide resulted in background staining.

and RPE cells (Fig 6). Of particular interest, the cellular pattern of androgen receptor staining in specific ocular tissues appeared to be independent of sex. Thus, the location of androgen receptor protein in a given lacrimal, meibomian, bulbar conjunctival, or corneal tissue appeared to be the same, regardless of whether the sample originated from a male or a female.

In these experiments, the specificity of androgen receptor staining was verified by employing a variety of controls. Thus, preincubation of the anti-androgen receptor antibody with excess amounts of the purified androgen receptor peptide "AR 1-21", which had served to generate the antibody, completely inhibited nuclear immunohistochemical staining in the lacrimal and meibomian glands, bulbar and forniceal conjunctivae, corneas, lens epithelial cells, and RPE cells (Figs 1-6), as well as in the LNCaP cells and rat prostatic tissues. In contrast, first antibody pre-exposure to the non-reactive androgen receptor peptide "AR 462-478" did not interfere with the expression of androgen receptor protein in any of the tissues or cells. In other control studies, replacement of the first antibody with either $0.1 \%$ gelatin/PBS or with an irrelevant rabbit IgG antibody preparation led to the absence of specific staining in all samples.

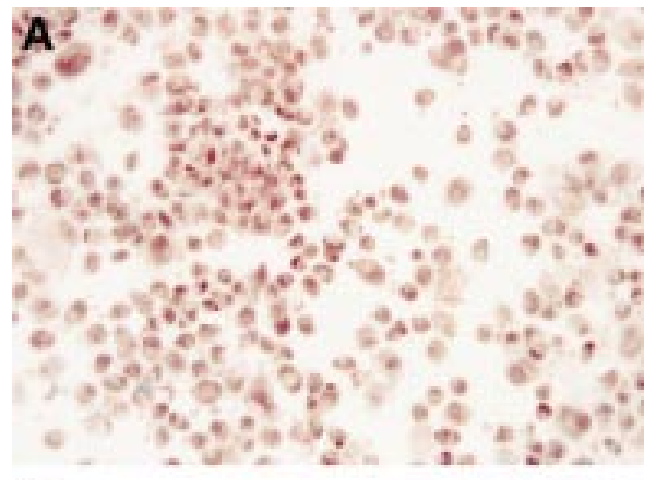

B

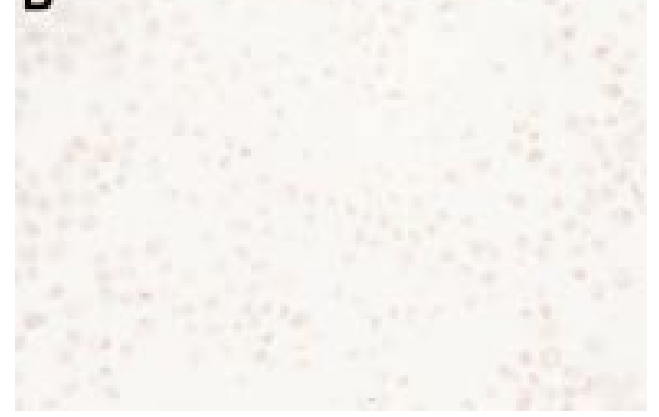

Figure 6 Identification of androgen receptor protein in the nuclei of retinal pigment epithelial cells. The cells were obtained from a 71 year old man following a cardiac arrest and were cultured until utilisation in this

immunoperoxidase study. For analysis, cultured cells were cytocentrifuged onto poly-L-lysine coated glass slides $\left(10^{5}\right.$ cells/slide), fixed in acetone for 5 minutes at $4^{\circ} \mathrm{C}$, and then processed for receptor staining. To confirm the specificity of the first antibody staining $(A)$, an aliquot of the rabbit anti-human androgen receptor was preincubated with an excess amount of peptide "AR1-21" (B).

PRESENCE OF TYPES 1 AND $25 \alpha$-REDUCTASE mRNA IN HUMAN OCULAR TISSUES

To determine whether the mRNAs for types 1 and $25 \alpha$-reductase exist in human ocular tissues, the following experiment was conducted. Lacrimal glands $(n=3)$, isolated meibomian glands $(n=5)$, bulbar conjunctivae ( $n$ $=6)$, corneas $(n=8)$, and RPE cells (2 separate cultures) from women and/or men were obtained (Table 2) and processed for molecular biological procedures.

Analysis by RT-PCR and agarose gel electrophoresis indicated that both types 1 and 2 $5 \alpha$-reductase mRNA are present in the human lacrimal gland, meibomian gland, bulbar conjunctiva, cornea, and RPE cells (Fig 7). Indeed, with the exception of one sample, all tissues and cells contained these PCR bands (Table 2). Amplified cDNA products with identical sizes for types 1 and $25 \alpha$-reductase were also present in the positive control human prostate, LNCaP epithelial cell and $\mathrm{Hs} 68$ fibroblast preparations (Fig 7), but absent in the negative controls.

The identity of these cDNA products was confirmed in lacrimal and meibomian gland samples, as well as in the positive controls, by Southern blot hybridisation. These studies also showed that the radiolabelled oligomeric probes used for the identification of amplified types 1 and $25 \alpha$-reductase cDNA fragments were specific and did not cross react with the types 2 and 1 products, respectively. To 
Table 2 Presence of types 1 and 2 5a-reductase mRNA in human ocular tissues and cells

\begin{tabular}{|c|c|c|c|c|c|}
\hline \multirow[b]{2}{*}{ Tissue } & \multirow[b]{2}{*}{ Sex } & \multirow[b]{2}{*}{ Age } & \multirow[b]{2}{*}{ Pathology } & \multicolumn{2}{|c|}{ 5a-Reductase $m R N A$} \\
\hline & & & & Type 1 & Type 2 \\
\hline Lacrimal gland & female & 82 & sebaceous gland carcinoma & + & + \\
\hline Lacrimal gland & male & elderly & hypertrophy & + & + \\
\hline Lacrimal gland & male & 80 & & + & + \\
\hline Meibomian gland & female & 82 & sebaceous gland carcinoma & + & + \\
\hline Meibomian gland & female & 79 & ectropion & - & - \\
\hline Meibomian gland & male & 58 & ectropion & + & + \\
\hline Meibomian gland & male & 68 & ectropion & + & + \\
\hline Meibomian gland & male & 74 & ectropion & + & + \\
\hline Bulbar conjunctiva ${ }^{\star}$ & female & $30,74,75$ & cataract, cataract, cataract & + & + \\
\hline Bulbar conjunctiva ${ }^{\star}$ & male & $32,66,76$ & pterygium, pterygium, cataract & + & + \\
\hline Corneat & female & $30,33,85$ & HSK, HSK, corneal scar & + & + \\
\hline Cornea† & male & $48,73,82$ & HSK, transplant rejection, $\mathrm{ABK}$ & + & + \\
\hline Corneał & male & 83 & heart disease & + & + \\
\hline RPE cells $\$$ & male & 71 & cardiac arrest & + & + \\
\hline
\end{tabular}

HSK $=$ herpes simplex keratitis; $\mathrm{ABK}=$ aphakic bullous keratopathy.

Tissues and cells were obtained and processed either individually or as combined preparations for molecular biological analysis. The designated samples of bulbar conjunctiva ${ }^{\star}$ and cornea ${ }^{\prime}$ were pools of three female or three male tissues. Similarly, two corneasł purchased from the eye bank were combined into one sample. The RPE (retinal pigment epithelial) cells originated from two separate cultures, which were derived from the same tissue. Both RPE cell preparations were positive for types 1 and $25 \alpha$-reductase mRNA. Data are reported as the presence $(+)$ or absence $(-)$ of the specific reductase isozyme, as determined by RT-PCR and agarose gel electrophoresis.

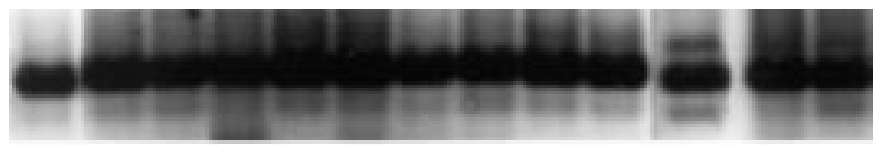

Type 2

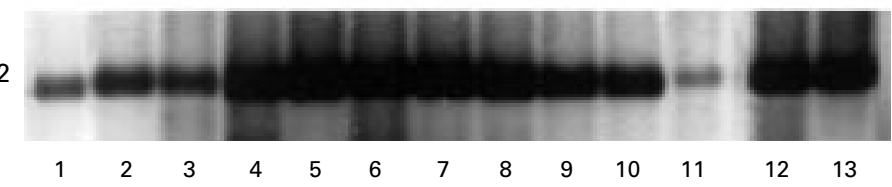

Figure 7 Presence of type $15 a$-reductase $m R N A$ (Type 1) and type 2 5a-reductase $m R N A$ (Type 2) in human ocular tissues and cells. Samples were processed for RT-PCR, agarose gel electrophoresis and ethidium bromide staining, as explained in Materials and methods. Photographs of agarose gels were obtained with a Polaroid camera (Polaroid Corporation, Cambridge, MA, USA) and images on the internegatives were then captured with a CCD-72S video camera (Hamamatsu Photonics, fapan), imported into Adobe Photoshop 4.01 and printed with a Kodak XLS 8600 printer. Samples 1-10 and 11-13 were run on parallel gels and bands have been aligned according to the molecular size of the bands. The numbers refer to the following samples: (1) male meibomian gland; (2) female meibomian gland; (3) female lacrimal gland; (4) male lacrimal gland; (5) prostate (surgical specimen); (6) Hs68 cells; (7) female conjunctiva ( $n=3$ combined tissues); (8) male conjunctiva ( $n=3$ combined tissues); (9) female cornea ( $n=3$ combined tissues); (10) male cornea ( $n=3$ combined tissues); (11) retinal pigment epithelial cells; (12) LNCaP cells; (13) prostate (RNA from Clontech).

definitively establish that the RT-PCR products represented types 1 and $25 \alpha$-reductase cDNA, the amplified cDNA fragments from a male meibomian gland and a prostate sample, respectively, were purified and subjected to DNA sequence analysis. The resulting sequences matched those in the GenBank database, thereby verifying the identity of these products (data not shown).

In these experiments no forniceal conjunctiva or lens epithelial cells were available for $5 \alpha$-reductase mRNA analysis.

\section{Discussion}

The present study demonstrates that androgen receptor protein exists within epithelial cell nuclei of the human lacrimal gland, meibomian gland, bulbar and forniceal conjunctivae, and cornea, as well as in nuclei of lens epithelial cells and RPE cells. In addition, our results show that the mRNAs for types 1 and 2 $5 \alpha$-reductase occur in the human lacrimal gland, meibomian gland, bulbar conjunctiva, cornea, and RPE cells. Collectively, these findings indicate that multiple ocular tissues in humans are target sites for androgen action and may possess the innate ability to convert testosterone to DHT.

Our identification of androgen receptor protein in epithelial cell nuclei of various ocular tissues suggests that androgens influence the structural organisation, functional activity, and/or pathological features of the anterior and posterior segment through a "classic" (that is, nuclear receptor mediated) mechanism. However, with the possible exception of the lacrimal and meibomian glands, the extent to which androgens regulate ocular processes through these receptors remains unclear.

More specifically, it has been recognised for decades that androgens exert a profound impact on the morphology, biochemistry, physiology, immunology, molecular biology, and protein secretory capacity of the lacrimal gland in a variety of species, ${ }^{1}$ and that this hormone action may account for many of the sex related differences that are found in this tissue. ${ }^{1}$ Similarly, recent evidence indicates that androgens regulate meibomian gland function, enhance the quality and/or quantity of lipids produced by this tissue, and promote the formation of the tear film's lipid layer in experimental animals and humans. ${ }^{416}$ Indeed, these androgen effects on the lacrimal and meibomian glands have led to our hypothesis that androgen deficiency, such as occurs during certain autoimmune diseases (for example, Sjögren's syndrome, systemic lupus erythematosus, rheumatoid arthritis), ${ }^{44}$ menopause, ${ }^{45}$ aging in both sexes, ${ }^{45}$ androgen insensitivity, ${ }^{46}$ and the use of anti-androgen medications (for example, for prostatic hypertrophy or cancer), is a critical aetiological factor in the promotion of tissue dysfunction and in the pathogenesis of dry eye syndromes. ${ }^{2}{ }^{17}$ If this hypothesis is correct, then topical androgen administration may potentially serve as a safe and effective therapy for the treatment of both aqueous deficient and evaporative dry eye in androgen deficient people. $^{217}$

In contrast with these findings, relatively little information exists concerning the nature of androgen effects on the conjunctiva, cornea, lens, or retina. Investigators have reported that androgens may significantly alter the development of allergic conjunctivitis in rabbits ${ }^{5}$ and that these hormones may have a beneficial influence on the corneal epithelium, acting to correct defects, facilitate wound healing, ${ }^{6} 74$ suppress angiogenesis, ${ }^{48}$ and stimulate mitosis. ${ }^{15}$ In fact, a pharmaceutical firm in South America (Laboratórios Frumtost SA/ Allergan-Lok, Guarulhos, Brazil) has marketed topical androgens for the therapy of corneal trauma, cicatrisation, erosions, ulcers, and atrophy, as well as for promoting postoperative care after corneal transplantation. Androgens are also known to prevent the inflammation induced loss of proteoglycans in non-ocular sites, ${ }^{49}$ but whether these hormones exert a similar effect in the cornea, and thereby 
influence corneal transparency, has yet to be elucidated. With regard to the lens and retina, it is unclear whether androgen-receptor interactions have a role in the sex associated differences observed in the density of lens epithelial cells or visual acuity, ${ }^{50}{ }^{51}$ or in the incidence of cataracts, macular holes, age related maculopathy, macular degeneration, or diabetic retinopathy. ${ }^{52-57}$ Androgens have been reported to modify the rate of progression of diabetic retinopathy, ${ }^{9}$ but whether this influence, if true, has any relation to receptors in RPE cell nuclei is unknown.

It is important to note that androgen actions on the eye and adnexal tissues may not be mediated solely through nuclear receptors. Androgens may also possibly act on the anterior and posterior segments through "nonclassic" processes. These hormone effects, which are typically very rapid (for example, seconds or minutes), involve alterations in membrane fluidity, control of neurotransmitter receptors and interaction with stereospecific plasma membrane receptors. ${ }^{58}$ Moreover, androgens may theoretically influence the human eye by associating with sex hormone binding globulin, which may interact with a cell surface receptor. This binding would then result in the stimulation of adenylyl cyclase, production of cAMP, activation of protein kinase A, phosphorylation of a cAMP response element binding protein and ultimately control of a gene's cAMP response element, thereby influencing transcription. ${ }^{59}$ As one additional consideration, it is also possible that the nuclear androgen receptors in the eye may be susceptible to activation by growth factors. Thus, proteins such as insulin-like growth factor I, epidermal growth factor, or keratinocyte growth factor may induce these receptors to become transcriptionally active in the absence of the androgen ligand. ${ }^{60}$ Whether these "nonclassic" pathways are operative in the eye, though, remains to be elucidated.

Our finding that numerous ocular tissues contain the mRNA for types 1 and 2 $5 \alpha$-reductase indicates that the human eye may be involved in the local conversion of testosterone to DHT. These $5 \alpha$-reductase enzymes, which are encoded by two different genes, ${ }^{39} 40$ are typically located in the endoplasmic reticulum and nuclear membrane.$^{61}$ Their activity, in turn, is essential for the formation of potent androgen metabolites throughout the body. ${ }^{18203940}$ Our observation that both types of reductase mRNA are present in the eye and adnexal tissues is not surprising, given that these enzymes are known to be transcribed and translated together in non-ocular sites. ${ }^{42} 62$ However, whether both of these isozymes are translated in ocular tissues, and act to modulate androgen metabolism, has yet to be clarified. In the future it will be of particular interest to determine whether human ocular tissues also contain the other steroidogenic enzymes, including steroid sulphatase, $3 \beta$-hydroxysteroid dehydrogenase $/-\Delta-{ }^{5} \Delta^{4}-$ isomerase (two forms), 17 $\beta$-hydroxysteroid dehydrogenase (five forms), aromatase, UDPglucuronosyltransferase, and sulphotrans- ferase, ${ }^{18} 2063$ which are necessary for local sex steroid synthesis and intracrine action. If so, this enzymatic machinery could represent the primary source of androgens, as well as oestrogens, that act on the human eye.

It should be noted that our control experiments indicate that prostatic epithelial cells (that is, $\mathrm{LNCaP}$ ) express both types 1 and 2 $5 \alpha$-reductase mRNA. This finding appears to conflict with the results of a recent study, which reports that only type 1 transcripts may be detected in these cells. ${ }^{64}$ However, other researchers have also identified type $25 \alpha$ reductase mRNA in cultured human prostatic epithelial cells, whether primary, ${ }^{42}$ immortalised, ${ }^{65}$ or LNCaP (Van Luu-The, Quebec, Canada, personal communication). The extent of this mRNA expression is apparently very dependent upon the nature of the culture conditions (Luu-The, personal communication)..$^{42}$

It should also be noted that our experiments were performed with tissues obtained from many individuals, some of whom had diseases that may have influenced the ocular expression of androgen receptor protein and/or $5 \alpha-$ reductase mRNA. Whether such pathological conditions might enhance or suppress receptor or enzyme presence, though, awaits clarification.

Lastly, investigators have recently discovered that the placental hormone, human chorionic gonadotropin (hCG), as well as the anterior pituitary hormone, luteinising hormone (LH), decrease the levels of androgen receptor and $5 \alpha$-reductase proteins in the skin of women. ${ }^{66}$ If hCG and LH have similar effects in the eye, then these actions could theoretically contribute to the diverse changes that occur in ocular tissues during pregnancy ${ }^{67}$ and the menstrual cycle. ${ }^{68}{ }^{69}$ Such a possibility, though, remains to be explored.

The authors wish to thank Drs Cheema, Choi, Daher, Kenyon, Ono, Rapoza, Shore, Townsend, Dorey, Shinahara, Ubels, and Prins for their provision of clinical samples or experimental materials. This research was supported by grants from NIH (EY05612), Allergan, Inc (Irvine, CA, USA), and the Massachusetts Lions Research Fund.

1 Sullivan DA, Wickham LA, Rocha EM, et al. Influence of gender, sex steroid hormones and the hypothalamicpituitary axis on the structure and function of the lacrimal gland. Adv Exp Med Biol 1998;438:11-42.

2 Sullivan DA, Wickham LA, Krenzer KL, et al. Aqueous tear deficiency in Sjögren's syndrome: possible causes and potential treatment. In: Pleyer U, Hartmann C, Sterry W, eds. Oculodermal diseases - immunology of bullous oculo-mucocutaneous disorders. Buren, Netherlands: Aeolus Press, cutaneous disord

3 Sullivan DA. Ocular mucosal immunity. In: Ogra PL, Mestecky J, Lamm ME, Strober W, McGhee J, Bienenstock , eds. Handbook of mucosal immunology. 2nd ed. Orlando, FL: Academic Press, 1999:1241-81.

4 Sullivan DA, Rocha EM, Ullman MD, et al. Androgen regulation of the meibomian gland. Adv Exp Med Biol 1998;438:327-31

5 Saruya S. Studies on allergic conjunctivitis. Effects of castration and sex hormone administration on experimental allergic conjunctivitis. Acta Soc Ophthalmol fap 1968;72: $833-45$

6 Hitawari S. Protein anabolic steroids in ophthalmology. Ber Dtsch Ophthal Ges 1963;65:424-6.

7 Schumacher H, Machemer R. Experimental investigations on the treatment of cortisone lesions of the cornea. Klin Monatsbl Augenheilkd 1966;148:121-6.

8 Matsuzawa A, Wada E. Retarded and distinct progress of lens opacification in congenic hereditary cataract mice, lens opacification in congenic hereditary

9 Haffner SM, Klein R, Dunn JF, et al. Increased testosterone in type I diabetics with severe retinopathy. Ophthalmology 1990;97:1270-4. 
10 Williamson JR, Chang K, Tilton RG, et al. Increased vascular permeability in spontaneously diabetic $\mathrm{BB} / \mathrm{W}$ rats and in rats with diabetes. Prevention by aldose reductase inhibitors and castration. Diabetes 1987;36:813-21.

11 Callard GV, Kruger A, Betka M. The goldfish as a model for studying neuroestrogen synthesis, localization, and action in the brain and visual

12 Popper P, Farber DB, Micevych PE, et al. TRPM-2 expression and tunel staining in neurodegenerative diseases: studies in wobbler and rd mice. Exp Neurol 1997;143:246-54.

13 Knepper PA, Collins JA, Frederick R. Effect of dexamethasone, progesterone, and testosterone on IOP and GAGs in the rabbit eye. Invest Ophthalmol Vis Sci 1985;26:1093100 .

14 Knepper PA. Method for the prevention of ocular hypertension, treatment of glaucoma and treatment of ocular hypertension. US Patent $4,617,299$.

15 Tsai TH, Scheving LE, Scheving LA, et al. Sex differences in circadian rhythms of several variables in lymphoreticular organs, liver, kidney, and corneal epithelium in adult CD2F mice. Anat Rec 1985:211:263-70.

16 Zeligs MA, Gordon K. Dehydroepiandrosterone therapy for the treatment of dry eye disorders. International patent application WO 94/04155, March, 1994.

17 Sullivan DA, Wickham LA, Rocha EM, et al. Androgens and dry eye in Sjögren's syndrome. Ann NY Acad Sci 1999 876:312-24.

18 Labrie F, Bélanger A, Simard J, et al. DHEA and peripheral androgen and estrogen formation: intracrinology. Ann NY Acad Sci 1995;774:16-28.

19 Clark JH, Schrader WT, O'Malley BW. Mechanisms of action of steroid hormones. In: Wilson JD, Foster DW, eds. Williams textbook of endocrinology. Philadelphia: WB Saunders, 1992:35-90.

20 Labrie F. Intracrinology. Mol Cell Endocr 1991;78:C113-18.

21 Simental JA, Sar M, Lane MV, et al. Transcriptional activation and nuclear targeting signals of the human androgen tion and nuclear targeting signals of the
receptor. $\mathcal{F}$ Biol Chem 1992;266:510-18.

22 Rundlett SE, Wu X-P, Miesfeld RL Functional characterizations of the androgen receptor confirm that the molecular basis of androgen action is transcriptional regulation. Mol Endocr 1990;4:708-14.

23 Southren AL, Altman K, Vittek J, et al. Steroid metabolism in ocular tissues of the rabbit. Invest Ophthalmol 1976;15: $222-8$

24 Stárka L, Obenberger J. Testosterone metabolism in various tissues of the intact and inflamed rabbit eye. Ophthalmic Res 1976;8:373-8.

25 Lanthier A, Patwardhan VV. In vitro steroid metabolism by rat retina. Brain Res 1988;463:403-6.

26 Stárka L, Obenberger J. In vitro estrone-estradiol-17 $\beta$ interconversion in the cornea, lens, iris and retina of the rabbit eye. Albrecht v Graefes Archiv klin exp Ophthal 1975;196: 199-204.

27 Sullivan DA, Edwards JA, Wickham LA, et al. Identification and endocrine control of sex steroid binding sites in the lacrimal gland. Curr Eye Res 1996;15:279-91.

28 Toda I, Wickham LA, Sullivan DA. Gender and androgen treatment influences the expression of proto-oncogenes and apoptotic factors in lacrimal and salivary tissues of MRL/lpr mice. Clin Immunol Immunopath 1998;86:59-71.

29 Rocha FJ, Wickham LA, Pena JDO, et al. Influence of gender and the endocrine environment on the distribution of androgen receptors in the lacrimal gland. F Ster Biochem Mol Biol 1993;46:737-49.

30 Ono M, Rocha FJ, Sullivan DA. Immunocytochemical location and hormonal control of androgen receptors in lacrimal tissues of the female MRL/Mp-lpr/lpr mouse model of Sjögren's syndrome. Exp Eye Res 1995;61:65966.

31 Ota M, Kyakumoto S, Nemoto T. Demonstration and characterization of cytosol androgen receptor in rat exorbital lacrimal gland. Biochem Int 1985;10:129-35.

32 Hahn JD. Effect of cyproterone acetate on sexual dimorphism of the exorbital lacrimal gland in rats. F Endocr 1969; 45:421-5.

33 Winderickx J, Hemschoote $\mathrm{K}$, De Clercq $\mathrm{N}$, et al. Tissue-specific expression and androgen regulation of different genes encoding rat prostatic 22-kilodalton glycoproteins homologous to human and rat cystatin. Mol Endocrin 1990;4:657-67.

34 Sullivan DA, Bloch KJ, Allansmith MR. Hormonal influence on the secretory immune system of the eye: androgen control of secretory component production by the rat exorbital gland. Immunology 1984;52:239-46.

35 Lambert RW, Kelleher RS, Wickham LA, et al. Neuroendocrinimmune modulation of secretory component production by rat lacrimal, salivary and intestinal epithelial cells. Invest Ophthalmol Vis Sci 1994;35:1192-201.

36 Ploc I, Sulcová J, Stárka L. Androgen uptake in the epithelium of the bovine cornea. Ophthalmic Res 1978;10:16-21.

37 Ploc I, Stárka L. Testosterone binding in the cytosol of bovine corneal epithelium. Exp Eye Res 1979;28:111-19.

38 Prins GS, Birch L, Greene GL. Androgen receptor localization in different cell types of the adult rat prostate. tion in different cell types of
Endocrinology 1991;129:3187-99.

39 Andersson S, Russell DW. Structural and biochemical properties of cloned and expressed human and rat steroid 5a-reductases. Proc Natl Acad Sci USA 1990;87:3640-4.
40 Andersson S, Berman DM, Jenkins EP, Russell DW. Deletion of steroid $5 \alpha$-reductase 2 gene in male pseudoherDeletion of steroid 5 $\alpha$-reductase 2 gene in
maphroditism. Nature 1991;354:159-61.

41 Limonta P, Dondi D, Marelli MM, et al. Growth of the androgen-dependent tumor of the prostate: role of androgens and of locally expressed growth modulatory factors. I Steroid Biochem Mol Biol 1995;53:401-5.

42 Bayne CW, Donnelly F, Chapman K, et al. A novel coculture model for benign prostatic hyperplasia expressing both isoforms of $5 \alpha$-reductase. 7 Clin Endocrol Metab 1998;83:206-13.

43 Hirsch KS, Jones CD, Audia JE, et al. LY191704: A selective, nonsteroidal inhibitor of human steroid $5 \alpha$ reductase type 1. Proc Natl Acad Sci USA 1993;90:527781

44 Sullivan DA. Sex hormones and Sjögren's syndrome. $f$ Rheumatol 1997;24 (Suppl 50):17-32.

45 Labrie F, Belanger A, Cusan L, et al. Marked decline in serum concentrations of adrenal C19 sex steroid precursors and conjugated androgen metabolites during aging. $\mathcal{f}$ Clin Endocr Metab 1997;82:2396-402.

46 Imperato-McGinley J, Gautier T, Cai LQ, et al. The androgen control of sebum production. Studies of subjects with dihydrotestosterone deficiency and complete androge insensitivity. F Clin Endocrinol Metab 1993;76:524-528.

47 Hildebrandt PG. Erfahrungen mit einer lokalen anabolen Therapie bei Hornhauterkrankungen. Med Mschr 1974;8: 359-60.

48 Yamamoto T, Terada N, Nishizawa Y, et al. Angiostatic activities of medroxyprogesterone acetate and its analogues. Int $\mathcal{f}$ Cancer 1994;56:393-9.

49 Da Silva JA, Larbre JP, Seed MP, et al. Sex differences in inflammation induced cartilage damage in rodents. The influence of sex steroids. F Rheumatol 1994;21:330-7.

50 Guggenmoos-Holzmann I, Engel B, Henke V, et al. Cell density of human lens epithelium in women higher than in density of human lens epithelium in women highe
men. Invest Ophthalmol Vis Sci 1989;30:330-2.

51 Klein R, Klein BEK, Linton KLP, et al. The Beaver Dam eye study: visual acuity. Ophthalmology 1991;98:1310-15.

52 Klein BE. Lens opacities in women in Beaver Dam, Wisconsin: is there evidence of an effect Trans Am Ophthalmol Soc 1994;517-41.

53 Guyer DR, Gragoudas ES. Idiopathic macular holes. In: Albert DM, Jakobiec, FA, eds. Principles and practice of ophthalmology: basic sciences. Philadelphia: WB Saunders, 1994;2:883-89.

54 Kahn HA, Leibowitz HM, Ganley JP, et al. The Framingham eye study. I. Outline and major prevalence findings. Am F Epidemiol 1977;106:17-32.

55 Hiller R, Sperduto RD, Ederer F. Epidemiologic associations with nuclear, cortical, and posterior subscapular cataracts. Am f Epidemiol 1986;124:916-25.

56 Klein R, Klein BEK, Linton KLP. Prevalence of age-related maculopathy. The Beaver Dam eye study. Ophthalmology 1992;99:933-43.

57 Klein R, Klein BEK, Moss SE, et al. The Wisconsin epidemiologic study of diabetic retinopathy. II. Prevalence and risk of diabetic retinopathy when age at diagnosis is less than 30 years. Arch Ophthalmol 1984;102:520-6.

58 Brann DW, Hendry LB, Mahesh VB. Emerging diversities in the mechanism of action of steroid hormones. F Steroid Biochem Mol Biol 1995;52:113-33.

59 Lewin DI: From outside or in, sex hormones tweak prostate cells. F NIH Res 1996;8:29-30.

60 Culig Z, Hobisch A, Cronauer MV, et al. Activation of the androgen receptor by polypeptide growth factors and cellular regulators. World f Urol 1995;13:285-9.

61 Moore RJ, Wilson JD. Localization of the reduced nicotinamide adenine dinucleotide phosphate: $\Delta^{4}$-3-ketosteroid $5 \alpha$-oxidoreductase in the nuclear membrane of the rat ventral prostate. F Biol Chem 1972;247:958-67

62 Mestayer C, Berthaut I, Portois MC, et al. Predominant expression of $5 \alpha$-reductase type 1 in pubic skin from normal subjects and hirsute patients. $\mathcal{F}$ Clin Endocrinol Metab 1996;81:1989-93.

63 Labrie F, Bélanger A, Cusan L, Candas B. Physiological changes in dehydroepiandrosterone are not reflected by serum levels of active androgens and estrogens but of their metabolites: intracrinology. 7 Clin Endocr Metab 1997;82: 2403-9.

64 Negri-Cesi P, Poletti A, Colciago A, et al. Presence of $5 \alpha$-reductase isozymes and aromatase in human prostate cancer cells and in benign prostate hyperplastic tissue.
Prostate 1998;34:283-91.

65 Berthaut I, Mestayer C, Portois MC, et al. Pharmacological and molecular evidence for the expression of the two steroid $5 \alpha$-reductase isozymes in normal and hyperplastic human prostatic cells in culture. Prostate 1997;32:155-63.

66 Bird J, Li X, Lei ZM, et al. Luteinizing hormone and human chorionic gonadotropin decrease type 25 a-reductase and androgen receptor protein levels in

67 Imafidon C, Akingbade A, Imafidon J, et al. Anterior segment adaptations in gestation. Optom Today 1993;April 5.

68 Serrander A-M, Peek KE. Changes in contact lens comfort related to the menstrual cycle and menopause. A review of articles. F Am Optom Assoc 1993;64:162-6.

69 Guttridge NM. Changes in ocular and visual variables during the menstrual cycle. Ophthal Physiol Opt 1994;14:38- 